Yu. A. Turlova ${ }^{1}$, orcid.org/0000-0003-0508-2087, H.S. Polishchuk ${ }^{2}$, orcid.org/0000-0002-0829-2621
1 - National Prosecution Academy of Ukraine, Kyiv, Ukraine, e-mail: turlova@ukr.net

2 - National Academy of Internal Affairs, Kyiv, Ukraine

\title{
CERTAIN TOPICAL ISSUES OF CRIMINALIZATION OF ILLEGAL AMBER MINING
}

Purpose. To study criminalization of encroachments which involve illegal amber mining, this being of independent importance for legislative as well as for law application activities.

Methodology. The system of general scientific and special methods and approaches which supported an objective analysis of the issue under study, in particular, the formal logical, logical and normative, and documentary methods, as well as the method of statistical analysis.

Findings. Certain problems have been identified which come to light in the course of establishing the prohibition of the investigated criminal practices at the legislative level, under criminal law, in particular the discrepancy between criminalization of illegal amber mining and the prerequisite for relative abundance; the study also reveals the permeability of the law on criminal liability for smuggling of amber and the group component of illegal amber mining, and activities related thereto.

Originality. The article, for the first time, analyzes the innovation of criminal legislation - article $240^{1}$ of the Criminal Code of Ukraine "Illegal Mining, Sale, Purchase, Transfer, Shipment, Transportation, and Processing of Amber" and the relevant draft laws from the perspective of their compliance with the requirements of the criminalization theory, which provided the grounds for justification of the proposals aimed at improving the current criminal legislation and the practice of its application by law enforcement agencies of Ukraine in terms of combating illegal amber mining.

Practical value. The work examines whether the provisions establishing liability for illegal mining, sale, purchase, transfer, shipment, transportation, and processing of amber comply with such a prerequisite for criminalization as relative abundance. The conclusion is made that in the current version of the law, illegal amber mining does not comply with this prerequisite. The author substantiates the position that it would be reasonable to construct the provision establishing the main corpus delicti, as the substantive one, as it could provide clearer criteria for criminalization. The author also proposes to formalize the consequences of illegal amber mining activity having the object filled with economic content, by making a quantitative assessment of the damage caused by the crime. This will allow reflecting the inflicted damage via economic categories and will provide for a greater efficiency of law application. Furthermore, the author proves that it would be expedient to supplement the disposition of part 2, article $240^{1}$ of the Criminal Code with such a qualificatory indicium as commission of the mentioned crime by a group of persons in collusion, and also to provide for criminalization of amber smuggling by appropriate amendments to part 1 , article 201 of the Criminal Code of Ukraine.

Keywords: illegal amber mining, criminalization, criminal law provision, Criminal Code, disposition, formalization

Introduction. Contradictions of environmental and economic interests of society, which are actualized by dissemination of the ideology of consumerism, i.e., development of "the civilization of consumption", bring about an intensified exploitation of natural resources and result in an excessive load on all elements of the environment and in its imbalance, which, more specifically, can be seen in the increasing consumption of irreplaceable natural and mineral resources and intensive development of mineral deposits. A bright illustration of this trend is the problem with illegal amber mining which has assumed a dangerous momentum in Ukraine. Due to the large-scale criminal mining, along with significant economic losses, dozens of hectares of woodlands and commercial lands are destroyed within the territory of Ukrainian Polissia, soil and vegetation cover is deteriorated, and the fertile land layer is damaged, thus creating a menace for an environmental disaster.

The most important tasks to be identified in this context include development of the lines of criminal-law protection of the environment from criminal activities involving illegal mining of amber. Therefore, research into and solution of the theoretical and application issues in this realm is of relevance for legal science.

Literature review. Research conducted by various authors on the development of the issues pertaining to criminal-law protection of the environment has formed a large body of scientific information.

The theoretical and practical issues of the criminal-law framework for countering environmental crimes, including those related to illegal mining of amber, were addressed by

(C) Turlova Yu.A., Polishchuk H. S., 2020 prominent national and foreign scientists, namely, S. B. Gavrysh, A. P. Hetman, O. L. Dubovyk, E. M. Zhevlakov, N. G. Ivanova, N. R. Kobetska, O. M. Kostenko, T. V. Korniakova, M. H. Maksimentsev, V. K. Matviichuk, O. V. Melnyk, I. I. Mytrofanov, V. O. Navrotskyi, N. L. Romanova, L. S. Khmurovska, Yu. S. Shemshuchenko and others in their works.

Unsolved aspects of the problem. However, despite the obvious importance of scientific developments in this realm, some of the problematic points of this topic remain insufficiently investigated; in the national literature, issues of criminalization of such encroachments have received only a fragmentary focus, being studied mainly within the framework of common crimes against the environment. The study on the process through which a criminal law ban is formed has also been overlooked by scientists, particularly, the stage of making a decision on the need for criminalization of illegal amber mining and related acts, for formulating of relevant criminallaw provisions, as well as for making of a scientific analysis of the most recent draft bills in this area and the innovations of criminal legislation.

The article focuses on studying the criminalization of encroachments involving illegal mining of amber, which is of standalone significance for legislative as well as for law application activities.

Methods. The methodological basis of the research rests upon the system of general scientific and special methods and approaches which made possible an objective analysis of the subject-matter under research. The formal logical method allowed formulating the concepts used to criminalize the encroachments involving illegal amber mining and eliminating inaccuracies and contradictions, in particular with the aim of achieving consistency of the title and content of the corre- 
sponding article of Ukraine's Criminal Code (hereinafter Ukrainian CC). The logical and normative method is used to analyze draft laws in this area and to develop amendments and additions to the current version of article $240^{1}$ of Ukrainian CC. The documentary method and statistical analysis enabled an assessment of the main statistical indicators reflecting the prevalence of illegal amber mining, in particular its group component.

Results. An analysis of criminological information sources which testify to the large-scale illegal mining of amber provides sufficient grounds for the conclusion that this situation also calls for using adequate measures of criminal-law response, which is understood as activities of the State, through its authorized bodies, with the aim of responding to actually committed encroachments by establishing criminal-law provisions which prohibit such behavior and prescribe appropriate penalties and other criminal-law measures against those who breach such prohibitions, as well as factual activities of law enforcement agencies aimed at the practical application of the measures to counter these encroachments formulated at the State level.

The efficiency of criminal-law response to environmental crime is primarily based on the perfection of the provisions establishing liability for environmental encroachments. Therefore, criminal legislation in this realm should meet the requirements of logic, balance, internal consistency and systematicity [1].

Compliance with these requirements, and the scope of criminal-law protection of the environment are determined by criminalization of environmental encroachments, that is, in the course of identifying and defining a socially dangerous act, which encroaches on the environment, as a criminal act.

The author's research in this respect was based on a systematic and consistent analysis of whether these encroachments developed by criminal law science comply with social and systemic legal prerequisites for criminalization. Generally, the system of these prerequisites may be outlined as follows: principles which express social demand and political expediency of establishing criminal liability. They can also be defined as social and socio-psychological ones, i.e., principles that ensure social adequacy of criminalization, its acceptability in terms of the fundamental characteristics of social systems and social development processes, compliance of criminal-law provisions with the level and nature of public consciousness and the state of public opinion; principles that define the requirements for internal logical consistency of the system of criminal law provisions, consistency between the provisions of criminal and criminal procedure law, as well as other branches of law - constitutional, economic, administrative, civil, and so on.

The most crucial prerequisite for criminalization is a sufficiently high level of public danger which manifests itself in the objective nature of the harm caused by encroachments of this category (environmental, material, moral harm). Environmental crimes in general and illegal amber mining in particular are among the most socially dangerous and widespread acts. Together with other offences in this area and given the severity of their consequences, they pose a real threat to national security.

Thus, every year illegal activities of residents in certain regions of Ukraine (experts report that more than 50 thousand persons are involved in illegal amber mining) [2]. For the impoverished villages of Polissia which are located near amber deposits in the State experiencing an economic downturn, illegal mining is a weighty source of income. For many residents of this region of Polissia, amber has become a kind of panacea for poverty. A harsh financial situation has driven them to illegal, often dangerous, mining activities. In social media, the situation with illegal mining is often referred to as the Amber People's Republic, with an emphasis being made on its likeness to corruption and disregard for Ukrainian legislation in the so-called Luhansk and Donetsk pseudo-republics in Eastern Ukraine [3].

According to the most conservative estimates, illegal mining of amber reaches 120 tons annually. However, experts report that the mined volume may actually reach 300 tons. In terms of money, illegal amber turnover amounts to USD 200300 million annually [4].

The economic damage which such activities bring about is not only a significant amount of revenues to the State Budget lost, but also the engendered powerful incentives for unfair competition and the resulting deformed market conditions in this area.

Moreover, the extent of public danger of an encroachment subject to criminalization is also determined by how it is committed, this being a qualitative characteristic of the danger which a respective illegal practice poses to the environment, i.e., showing how the crime was committed, as well as which methods and means were directly used in the case concerned.

Therefore, within the framework of the study into the factors determining the choice of a certain method to commit an act of illegal amber mining, it is worth noting that along with its intentional aspect (what should be achieved), the act also has its operational aspect (how it can be achieved), and this is determined not by the goal itself, but objectively by particular conditions for achieving the goal [1].

The choice of modus operandi of illegal amber mining stems from the factors characterizing a perpetrator's personality (moral and psychological characteristics, capabilities and skills), as well as from external factors, in particular, the place, time and circumstances of the act, and also from the specifics of the object of the environment which the encroachment is focused on.

Note should be made that the provisions establishing liability for environmental crimes contain, in the dispositions, six mentions of modus operandi of such crimes as a qualifying circumstance. More specifically, the generally dangerous way of committing environmental crimes is referred to four times, namely part 3 of article $239^{1}$ "Misappropriation of the soil cover (surface layer) of land" of the Criminal Code of Ukraine, part 4 of article 240 "Breach of the rules of protection or use of subsoil resources" of the Criminal Code of Ukraine, part 1 of article 245 "Destruction or damage of objects of flora" and part 2 of article 252 "Willful destruction or damage of territories protected by the State and sites of natural conservation" of the Criminal Code of Ukraine. Besides, there are two more references to the method of mass destruction: in part 2 of article 248 "Illegal hunting" and part 2 of article 249 "Illegal fishing or hunting or other sea hunting industry" of the Criminal Code of Ukraine [5].

Thus, the disposition of article $240^{1}$ of Ukraine's Criminal Code "Illegal Mining, Sale, Purchase, Transfer, Shipment, Transportation, and Processing of Amber" does not contain the signs which would indicate a generally dangerous way of committing these crimes. At the same time, the study on law application practice in this area evidences that modus operandi of the act of illegal amber mining, which is most often the hydraulic washing method with the use of appropriate technical facilities, is dangerous for the environment. Here it should be noted that possible application of technical (engineering) facilities and systems can significantly raise the level of danger of criminal practices. The general scheme of use of technical facilities is as follows: a compressor and a motor pump consisting of an engine and a fire pump are installed and adjusted near the likely place of amber occurrence. Water is fed under high pressure to the place where amber is likely to occur, and this creates a large pit through which amber is pushed up to the surface of water because it weighs less. Such an innovation makes it possible to wash a significant amount of precious stones in a short period of time without great risk to life and health.

However, the mass and long-term application of the hydraulic washing method to mine amber entails changes in the 
hydrological regime within large areas of Ukrainian land (experts report that it is already a matter of thousands of hectares). Accordingly, as a result of increased soil acidity, significant areas of forests and land are destroyed, forests and swamps actually disappear, rivers are polluted, soil and vegetation covers are damaged, the fertile layer of land is damaged or even lost, all these significantly limiting the possibility of further exploitation of the soil. Eventually, even if new trees are planted in the affected areas, they do not grow, or dry up. Experts say that in the damaged areas there will not be any full-fledged forest for 70-80 years. The forest which remains in these areas will get sick. Its root system is disrupted, and water supply of the trees is disrupted as well. As a consequence, either a sandy desert is formed, or a swampy area occurs if there was water supply for pumps. This brings about irreversible microclimatic changes in the territories of illegal amber mining $[2,4,6]$.

Both wind and water erosion has been recorded in the open areas not covered by forest where amber deposits are being developed. The effect of erosion processes is manifested in a decreased capacity of the humus horizon, soil structure loss, increased soil drought (desertification effect), and a decrease in nutrient reserves [7].

In other areas, excessive ground water disrupts root system stability, trees lose their vertical position. Trees with roots affected by water lean to form the so-called "drunk" forest which is dangerous for those who want to take a walk in it. There will be no restoration of full-grown woodlands for more than 70-80 years. The forest groups remaining on the sites of amber extraction are sick and rotting. Root systems of trees are damaged and their water supply is disrupted. As a consequence, sandy devastated landscapes are formed, and in case water was supplied to motor pumps, there are swampy areas over-saturated with water [3]

The cumulative impact of the factors described above can eventually lead to an environmental disaster.

Therefore, socially dangerous consequences of illegal amber mining take the form of a disastrous deterioration of the quality of the environment and the emergence of ecological disaster zones within the territories of criminal mining activities; degradation of natural resources which should be recoverable (fertility of soil and forest resources); direct depletion of nonrecoverable resources of amber which, along with significant economic value, also has social value manifested in its ability to meet the material and aesthetic needs of society; besides, due to the large-scale application of the hydraulic washing method, the quality of surface and underground water deteriorates.

Furthermore, there is an urgent problem of remediation of damaged land. Remediation of these lands is a major and at the same time extremely difficult task. Unfortunately, currently there is no well-developed technology for this, and the elements - pollutants of atmospheric air and ground water have not been studied yet. And note should be made that approximate estimates indicate that from UAH 100 to 400 thousand will be needed to restore 1 ha of woodland [4].

Therefore, given the intensity of criminal practices involving illegal amber mining, we can conclude that such activities fully meet the characteristics of "criminal industry" (systematicity, high profitability, tolerant attitude of society, legality of such activities in case of licensing by the State, transnational nature), and this also determines the public danger of these encroachments.

The authors believe that the above provisions pertaining to a research into public danger of illegal amber mining, the specifics and value of the object of the natural environment which the encroachment is focused on, the objective nature of harm ensuing from encroachments of this category, and also the danger intrinsic in the method for committing these encroachments, give grounds for the conclusion that there is an objective need for criminal-law protection of the environment from the most dangerous encroachments referred to the mentioned category.
With a view to assessing compliance of the proposed and current criminal law provisions with some of the above-mentioned prerequisites for criminalization, we believe that it would be reasonable to make an appropriate analysis of the most recent draft laws and innovations of criminal legislation in the realm of countering illegal amber mining.

As it is known, as a consequence of illegal amber mining and with the aim of enhancing the effectiveness of criminal law protection of the environment, a draft Law of Ukraine was developed "On Amendments to the Criminal Code of Ukraine Regarding Criminal Liability for Illegal Amber Mining or Amber Movement Across the Customs Border of Ukraine", Reg. No. 2059, dated 04.09.2019. This draft law proposed supplementing the Criminal Code of Ukraine with the new special provision, namely article $240^{1}$ "Illegal mining of amber", which provides for criminal liability for: illegal amber mining; sale, purchase, storage, transfer, shipment, transportation, processing of illegally mined amber; illegal mining of amber or its sale, purchase, storage, transfer, shipment, transportation, processing, committed by a group of persons upon a preliminary collusion, or repeatedly, or on a large scale (one hundred or more times exceeding the non-taxable minimum income of citizens), and also for illegal amber mining committed within the territories or sites of natural conservation. Furthermore, by appropriate amendments to article 961 "Special seizure" of Ukrainian CC, the draft law introduces special seizure for illegal amber mining [2].

Based on the analysis of the proposed criminal law provision, it may be concluded that there is a situation when the title of the article is inconsistent with its content, because the acts listed under part 2, article $240^{1}$ of Ukrainian Criminal Code, namely, sale, purchase, storage, transfer, shipment, transportation, processing of illegally mined amber as signs of an objective party do not agree with the name of the crime which refers only to mining. Therefore, it is unwarranted to use the term "mining" in the article's title, since its scope is narrower than the scope of the acts described in the disposition of the article and, therefore, the article has a discrepancy between its title and content. Apparently, in this situation, the title of the article should be changed or its content should be brought in line with the title. Another draft Law "On Amendments to Some Laws Regarding Criminal Liability for Illegal Amber Mining or Any Other Illegal Operations with Amber", Reg. No. 2059-1 dated 11.09.2019 [8] attempted at eliminating these legislative technique shortcomings; it contained another title of article $240^{1}-$ "Illegal Mining or Any Other Illegal Operations with Amber", and its part 1 listed the acts covered by the term "Other illegal operations with amber".

In our opinion, there is more perfection in the wording of this article added to Ukrainian CC according to Law of Ukraine No. 402-IX dated December 19, 2019 "On Amendments to Some Legislative Acts of Ukraine Regarding Improvement of Legislation on Mining of Amber and Other Mineral Resources" [9].

The new special provision is titled "Illegal mining, sale, purchase, transfer, shipment, transportation, and processing of amber" and contains three parts: the first of them establishes corpus delicti of the crime, lists relevant acts and describes the essence of the predicate "illegal", i.e., "when the legality of its origin is not confirmed by relevant documents"; the second and third parts provide for qualified corpus delicti (with aggravating circumstances, namely the acts committed repeatedly or on a large scale, or within the territories or sites of natural conservation) and particularly qualified corpus delicti (with particularly aggravating circumstances, namely the acts committed by an official by using his/her official position); these parts also establish the types of the crime concerned.

It is worth highlighting certain shortcomings of the legislative technique which, in our opinion, are present in the adopted criminal law provisions. Since corpus delicti of the 
crime provided for in article $240^{1}$ of Ukrainian CC is constructed as a formal one, this may engender law application problems which will arise in connection with qualification of respective offenses. As it is know, in the current Code, to resolve this problem, some corpora delicti which "border" on administrative offenses are constructed as substantive crimes, i.e., those considered as completed as soon as criminal consequences occur. In cases where corpus delicti is of a formal nature, signs which outline modus operandi, place, motives, and signs of a special subject are indicated. In article $240^{1}$ of Ukrainian $\mathrm{CC}$, these signs are when the crime is committed within the territories and sites of natural conservation (part 2, article $240^{1}$ of the Criminal Code) and committed by an official with the use of official position (part 3 of article $240^{1}$ of Ukrainian $\mathrm{CC})$.

However, the first part of this article mentions no such signs, and so an attempt to apply this criminal law provision will inevitably raise the question as to which amount of mined amber should be considered a criminal offense, and which an administrative offense (article 581 of the Code of Ukraine for Administrative Offenses) [10]. If this provision is applied to all (irrespective of the amount) cases of illegal acts with amber, this will be inconsistent with the requirement of "relative prevalence of the act" as a prerequisite for criminalization, the essence of which is that an act to be criminalized should be, on the one part, fairly widespread, i.e., it should have some general social patterns, and on the other part - it should not be very much common.

Given that the task of criminal law is to have a corrective effect on certain types of social relations and to formulate the general rules intended for repeated application, an encroachment requiring criminalization, i.e. illegal amber mining, should not be an isolated phenomenon, but should be a behavior which has the form of a certain type of activity and is likely to re-occur in the future.

Regarding illegal mining of amber, the prevalence of which is apparent, we can affirm with certainty that this form of antisocial behavior is not accidental or non-recurrent. So, over the past three years, investigative police units of Rivne, Volyn and Zhytomyr oblasts alone registered 1,534 prosecutions under article 240 of Ukrainian CC concerning illegal amber mining [2]. Given the significant latency of this criminal activity, its real scales are much larger. The prevalence of such practices is conditioned by the influence of a number of factors, which include the existing traditions of this illegal activity, legal nihilism, evident disrespect for environmental legislation, socioeconomic problems of the Ukrainian Polissia territories, low environmental and legal culture of the population, which brings about the prevailing standpoint that natural resources, particularly, amber, are inexhaustible, and hence the harm caused by this crime is regarded as insignificant. A significant impact is also due to the erroneous policy of the State with regard to legalization of business activities involving amber mining by individual citizens, prospectors' teams, and other business structures, as well as due to corruption, unwillingness and inability of law enforcement agencies to counteract illegal amber mining in an efficient manner. All these factors result in a high latency of illegal amber mining which, as shown by the survey of heads of local public prosecutor's offices and their first deputies, is estimated at the rate of $72.7 \%$ [11]. As M. H. Maksimentsev credibly argues, really large volumes of illegal mining of mineral resources (primarily raw amber and coal) are organized under the quasi-legal cover, and are backed by an extensive network of stable corruption ties and schemes, thus giving law enforcement agencies almost no chance of uncovering these activities and showing them in statistical records and other sources of empirical information suitable for processing, analysis and generalization with a high degree of formalization and representativeness [12].

As it is known, criminological science evidences that it is inappropriate and useless to criminalize a phenomenon if it has already been incorporated into mass everyday life. Firstly, from the standpoint of social and legal psychology, such criminal law provisions may not be perceived by those to whom they are addressed as consistent with the real situation and appropriate for application (at least, this can be affirmed with certainly with respect to the vast majority of the population). As it is known, the deterrent effect of a criminal law provision is targeted at a fairly extensive part of society, particularly, at the persons who are prone to breach the provision concerned, as well as at law-abiding persons, for whom such actions are incompatible with their moral, cultural, spiritual attitudes and values. It is apparent that the value-oriented impact of criminal prohibition of the behavior, which is mass and habitual, will have a minimal efficiency.

Secondly, if such a provision is applied totally, criminal liability should be imposed on a large number of persons who breach this provision. This would contradict the principle of avoiding excessive application of criminal repression, since both the adoption and the application of respective criminal law provisions is an exceptional (and not normal and widespread) means of legal regulation, which is appropriate only if all other legal means are ineffective.

Thirdly, an attempt to apply such a provision will not be the intended optimal measure (in terms of the appropriate proportion of the positive and negative consequences of its application) by which the goals of criminal punishment, as prescribed by law, are achieved. Therefore, given the above-mentioned, practical application of such a provision will either be selective, or it will become another "dead" rule in criminal legislation.

That is why, in the situation when illegal amber mining in Ukraine has become a routine for a major part of the Polissia population, if such behavior is termed as criminal, this would result, firstly, in discrediting criminal legislation, since the criminal justice authorities would not have a real opportunity to ensure its implementation, and secondly, in blurring the boundaries between criminal and non-criminal behavior, since a major part of society members would be actually recognized as criminals.

Therefore, where such acts are massive, widespread, wellorganized and professional, as it is the case with illegal amber mining, there is an apparent inconsistency with the specified requirements for criminalization, and in our opinion, this will lead to selective application of such a provision. We believe that one of the explanations for this situation is a certain imperfection of the disposition of part 1, article $240^{1}$ of Ukrainian $\mathrm{CC}$ which, due to its construction as a provision with the formal corpus delicti, does not require an evaluation of the damage inflicted by the crime, meaning that an assessment should be made both of the scope of criminal changes in the environment, as an object protected by criminal law, due to illegal amber mining, and of the substantive manifestations of environmental harm.

When defining the conditions for formalization of the environmental tort consequences, it should be borne in mind that this assessment is appropriate only with regard to the crimes encroaching on certain natural resources (mineral, land, forest, fish, hunting, and so on). Such crimes include: misappropriation of soil cover (surface layer) of land (article 239-1 of CC), misappropriation of lands of water resources on an especially large scale (article 239-2 of CC), violation of rules related to the protection or use of mineral resources (article 240 of CC), violation of law on the continental shelf of Ukraine (article 244 of CC), illegal cutting of forests (article 246 of CC), illegal hunting (article 248 of CC), illegal fishing, hunting or any other sea hunting industry (article 249 of CC), and illegal mining of amber (article $240^{1}$ of CC).

These natural resources are extracted and developed on the basis of respective current economic regulations governing the valuation of natural resources that have been lost or damaged as a result of a particular crime. More specifically, these 
losses are calculated according to special rates approved by the Cabinet of Ministers and orders of the State Forestry Committee of Ukraine. These include rates for calculating the amount of compensation for losses resulting from violations of game and hunting legislation (except for species listed in the Red Book of Ukraine); for calculating the amount of damage caused to forests by enterprises, institutions, organizations and citizens via illegal logging of and damage to trees and shrubs to the extent of stopping their growth; for calculating the amount of compensation for damage resulting from illegal extraction (gathering) or destruction by citizens of Ukraine, foreigners and stateless persons of valuable types of aquatic bioresources in fishing water bodies of Ukraine.

Given that in this case the object of the crime is also an economic category, since owing to extraction of mineral and other natural resources material wealth is created, appropriate conditions of human existence are maintained, and the proper quality of life of people is ensured, therefore, the use of economic criteria for their assessment is quite possible and welljustified. It is the economic content in the object of crimes referred to these categories that makes it possible to reflect respective losses statutorily through economic categories. Along with the above-mentioned, due to the specifics of cause-and-effect relationship in crimes of this category, losses occur immediately after the encroachment is committed, and this allows establishing it actually and calculating its quantitative scopes.

Obviously, this is also true for illegal amber mining. Failure to take these provisions into account when constructing a respective criminal law provision may engender a significant potential for corruption and create grounds for selective (at the subjective discretion of law enforcement officers) application of this provision.

Therefore, as a solution to this problem, clear criteria for criminalization should be introduced in article $240^{1}$ of Ukrainian CC. This would be logical, given that there are quantitative criteria of "large scale" (part 2, article $240^{1}$ of Ukrainian CC) defined by the article's note.

This approach, which involves formalization of the consequences, i. e. quantitative assessment of the damage inflicted, is typical only in relation to the encroachments of the "subject group" having the object filled with economic content, which allows reflecting the damage inflicted using economic categories [1].

Examples of such formalization in environmental crimes of the "subject group", which encroach on certain natural resources, are illegal logging or illegal transportation, storage, sale of forest (article 246 of Ukrainian CC), illegal fishing or hunting or other sea hunting industry (article 249 of Ukrainian $\mathrm{CC}$ ). The first parts of these criminal law provisions, which enshrine corpus delicti of respective crimes, are constructed as substantive, i.e., the criminality of the act is linked to whether significant damage is inflicted by it. Part 1 of article 248 "Illegal hunting" of Ukrainian CC constructs a more complex corpus delicti: it is substantive in terms of committing illegal hunting that caused significant damage, and formal where such actions are committed in nature reserves or other territories and sites of natural conservation, or when hunting animals, birds or other species of fauna listed in the Red Book of Ukraine.

By respective amendments to Ukrainian CC, articles 246 and 248 were supplemented with notes which quantified the amount of significant damage provided for by the dispositions of these articles. At the same time, there is no similar note to article 249 of Ukrainian CC, and this seems inconsistent and illogical, given that the issue calling for the adoption of such a note is sufficiently studied and common both in relation to illegal logging or illegal transportation, storage, sale of forest, illegal hunting, as well as to illegal fishing or hunting or other sea hunting industry.

We believe that the recently adopted provision establishing liability for illegal amber mining should be constructed similarly and should have clearer criteria for criminalization.
As noted above, one of the characteristics of the "criminal industry" associated with illegal mining of amber is its transnational nature. The industrial scale of illegal amber mining in Ukraine has entailed an increase in its value on the world market of precious stones. This is due to the cheapness and simplicity of the technology of artisanal amber mining given its near-surface occurrence, low employment in the regions of amber deposits, and corruption, including in governmental and law enforcement agencies, as well as minimal liability for illegal mining [3].

Today's realities show that illegal amber mining is closely linked to the activities of organized groups which have a transnational and economic focus and smuggle the mined amber to obtain super-profits. This situation highlights the problem of developing efficient measures to counteract amber smuggling, including by means of criminal law.

However, according to the content of the disposition of article 201 of Ukrainian CC "Smuggling", amber is not on the list of smuggled items. In practice, there is a typical situation when persons trying to take it out of Ukraine (most often to Poland) hide amber from customs control officers, because they can't officially submit shipping documents for it, as only individual enterprises holding an appropriate license have the right to mine amber. Therefore, if such persons are found to have amber during customs inspections, amber is seized from them on the grounds that they have hidden amber from the customs control, according to part 1, article 483 of the Customs Code of Ukraine. Concurrently with temporary (until judgment) seizure of amber at the checkpoint, the customs authority sends a respective notification to the National Police authorities concerning further procedural action on the grounds of article 198 of Ukrainian CC "Purchase, receipt, storage or sale of property obtained by criminal means". At the same time, as law application practice shows, it is almost impossible to prove the criminality of such acts, and this actually turns article 198 of Ukrainian CC into a "dead" rule.

It would be logical to expect that this situation may be remedied by adopting the above-mentioned Law of Ukraine "On Amendments to Some Laws Regarding Criminal Liability for Illegal Amber Mining or Any Other Illegal Operations with Amber". At the same time, the current version of the new provision - article $240^{1}$ of Ukrainian CC, which establishes corpus delicti and lists respective acts according to this law, in its part 1 does not contain such a sign as amber smuggling. Besides, this law disregarded the proposals contained in draft laws prepared earlier [2,8] for supplementing article 201 Ukrainian CC "Smuggling" with relevant provisions under which taking of amber across the customs border of Ukraine with bypassing the customs control or hiding amber from the customs control may be qualified as smuggling. The current situation allows affirming that there is a gap in the law on criminal liability for amber smuggling. Despite the fact that today Ukrainian CC does not actually provide for criminal liability for taking of amber across the customs border of Ukraine with bypassing the customs control or hiding amber from the customs control, there are good reasons to criminalize this illegal act involving amber by making respective amendments to article 201 "Smuggling" of Ukrainian CC.

A distinguishing feature of illegal amber mining is the dominating group component in its structure, which can be explained by the specifics of these criminal practices often requiring the coordinated collective action of accomplices. These encroachments which are committed by a group of persons pose a more considerable public danger because the damage is inflicted on a larger scale and a possibility arises to commit more sophisticated crimes which are either impossible or very problematic for one perpetrator.

In the scientific literature, we and other authors have already made suggestions about the need to criminalize group misappropriation of natural resources. This is also true for illegal amber mining. In reality, which is usually not adequately reported 
in official statistics, a major part of encroachments in this category is characterized by elements of organized criminal groups, by the intention of persons - professional amber miners to unite in stable formations, and by penetration of organized crime into the law enforcement branch. The organized nature of this criminal industry is also confirmed by the fact that the scale of illegal amber mining far exceeds its volume mined legitimately.

We are of the opinion that given the prevalence and an increased social danger of such crimes committed by a group of persons, with a view to adequately assessing these encroachments when they are qualified and sentenced and, eventually, with a view to enhancing the efficiency of counteraction of illegal amber mining by means of criminal law, it is reasonable to supplement the disposition of article $240^{1}$ of Ukrainian CC with the qualified corpus delicti in part 2 , so that this article prescribes liability for the acts specified in part 1 which are committed by a group of persons upon a preliminary collusion.

Conclusions. The authors' analysis of legislative activity focused on countering illegal amber mining revealed certain shortcomings which ensue from non-compliance with the legislative technique rules for constructing the dispositions of criminal law provisions. Following a research study into compliance with the prerequisites for criminalization of illegal amber mining in the context of adoption of an innovation in criminal legislation, a conclusion is made that these criminal practices, in the understanding of the current version of the law, are not consistent with the prerequisite of the relative prevalence of such acts. Arguments are provided to support the authors' position that it is reasonable to construct the provision establishing corpus delicti as a substantive provision, which would provide clearer criteria for criminalization and a higher efficiency of law enforcement activities. It is also proposed to supplement the disposition of part 2, article $240^{1}$ of the Ukrainian Criminal Code with such a qualifying sign as commission of the mentioned crime by a group of persons upon a preliminary collusion, and to criminalize amber smuggling by appropriate amendments to part 1 , article 201 of the Criminal Code of Ukraine.

\section{References.}

1.Turlova, Yu. A. (2018). Environmental Crime in Ukraine: Criminal Law and Criminological Foundations of Countering It: monograph. Kyiv: Znannia Ukrainy.

2. Verkhovna Rada of Ukraine (n.d.). On Amending the Criminal Law of Ukraine Regarding Criminal Liability for Illegal Amber Mining or Moving It across the Customs Border of Ukraine. Draft Law dated 04.09.2019 No. 2059. Retrieved from http:// w1.c1.rada.gov.ua/pls/zweb2/webproc4 1 ? pf3511 $=66672$.

3. Ivanov, Ye.A. (2019). Analysis of the Environmental Situation in the Areas of Illegal Amber Mining. Subsoil Management in Ukraine. Investing Prospects: Materials of the Sixth International Scientific and Practical Conference (October 7-11, 2019, Truskavets), (pp. 101-107). Kyiv: DKZ. Retrieved from http://conf.dkz.gov.ua/files/2019 materials vol 2 net.pdf. 4. Pravda (n.d.). 10 Facts about Ukrainian Amber. Retrieved from http://pravda.press/news/economic/10-faktiv-pro-ukrainskiyburshtin-22109.

5. Verkhovna Rada of Ukraine. Legislation of Ukraine (n.d.). Criminal Law of Ukraine: Law of Ukraine dated 05.04.2001 No.2341-III. Retrieved from https://zakon.rada.gov.ua/laws/ show/2341-14.

6. Illegal Mining of Amber Continues in Ukraine, Microclimate Changes are Irreversible in the Plundered Territories - Experts (n.d.). Retrieved from https://censor.net.ua/ua/ news/3200229/v ukrayini prodovjuyut nezakonno vydobuvaty burshtyn na rozgrabovanyh terytoriyah_nezvorotnymy ye zminy.

7. Nadtochii, P. P., \& Myslyva, T. M. (2015). Illegal Mining of Amber in Zhytomyr Oblast: Environmental Aspects. Amber Mining Problems in Ukraine and the Ways to Resolve Them. Series "Environmental Situation", 9(141), 6-10.
8. Verkhovna Rada of Ukraine (n.d.). On Amendments to Some Laws Regarding Criminal Liability for Illegal Amber Mining or Any Other Illegal Operations with Amber. Draft Law dated 11.09.2019. No. 2059-1. Retrieved from http://w1.c1.rada. gov.ua/pls/zweb2/webproc4 1?id=\&pf3511=66802.

9. Verkhovna Rada of Ukraine. Legislation of Ukraine (n.d.). On Amendments to Some Legislative Acts of Ukraine Regarding Improvement of Legislation on Mining of Amber and Other Mineral Resources: Law of Ukraine dated 19.12.2019 No. 402-IX. Retrieved from http://zakon.rada.gov.ua/laws/show/402-20\#n63. 10. Verkhovna Rada of Ukraine. Legislation of Ukraine (n.d.). The Code of Ukraine for Administrative Offenses. Law of Ukraine dated December 7, 1984 No. 8073-X. Retrieved from http://zakon.rada.gov.ua/laws/show/80731-10\#Text.

11. Turlova, Yu. A. (2016). On Determining the Level of Environmental Crime Latency. Topical Issues of State-Building in Ukraine: Materials of International Scientific and Practical Conference (Kyiv, May 20, 2016), (pp. 62-64). Kyiv: VPZ "Kyiv University". Retrieved from http://dsr.univ.kiev.ua/ pub/publish/209511/?SHOWALL_2=0.

12. Maksimentsev, M.H. (2018). Criminological Characterization of Individuals Committing the Crimes under Article 240 of the Criminal Code of Ukraine. Scientific Bulletin of the International Humanities University. Series "Jurisprudence", 36(2), 110-113.

\section{Деякі проблемні питання криміналізації незаконного видобування бурштину}

\section{Ю.А. Турлова ${ }^{1}$, Г. С. Полішук ${ }^{2}$}

1 - Національна академія прокуратури України, м. Київ, Україна, e-mail: turlova@ukr.net

2 - Національна академія внутрішніх справ, м. Київ, Україна

Мета. Дослідження криміналізації посягань, пов'язаних із незаконним видобутком бурштину, що має самостійне значення як для законотворчої, так і правозастосовної діяльності.

Методика. Система загальнонаукових та спеціальних методів і підходів, що забезпечили об'єктивний аналіз досліджуваного предмета, зокрема, формально-логічний, логіко-нормативний, документальний методи, а також метод статистичного аналізу.

Результати. Виявлені деякі проблеми, шо мають місце при законодавчому формуванні кримінально-правової заборони досліджуваних кримінальних практик, зокрема - невідповідність криміналізації незаконного видобування бурштину передумові відносної поширеності, а також наявна пробільність закону про кримінальну відповідальність щодо контрабанди бурштину та групової складової незаконного видобутку бурштину й пов'язаних із цим діянь.

Наукова новизна. У статті вперше проаналізована новела кримінального законодавства - стаття $240^{1}$ «Незаконне видобування, збут, придбання, передача, пересилання, перевезення, переробка бурштину» КК України та відповідні законопроекти стосовно відповідності вимогам теорії криміналізації, що дало можливість обгрунтувати пропозиції, спрямовані на удосконалення чинного кримінального законодавства та практики його застосування правоохоронними органами України у сфері протидії незаконному видобутку бурштину.

Практична значимість. У роботі досліджена відповідність норм, що встановлюють відповідальність за незаконне видобування, збут, придбання, передачу, пересилання, перевезення, переробку бурштину, такій передумові криміналізації, як відносна поширеність. Зроблено висновок, що незаконне видобування бурштину в розу- 
мінні чинної редакції закону не відповідає зазначеній передумові. Аргументована авторська позиція щодо доцільності побудови норми, яка встановлює основний склад злочину, як матеріальної, що забезпечило б більш чіткі критерії криміналізації. Запропонована формалізація наслідків незаконного видобування бурштину, об'єкт якого наповнений економічним змістом, шляхом кількісного оцінювання завданої злочином шкоди. Це дасть змогу відобразити завдану шкоду за допомогою економічних категорій і забезпечить більшу дієвість у правозастосовній діяльності. Доведена доцільність доповнення диспозиції частини 2 статті $240^{1}$ КК України такою кваліфікуючою ознакою як вчинення зазначеного злочину за попередньою змовою групою осіб, а також криміналізації контрабанди бурштину шляхом внесення відповідних доповнень до частини 1 статті $201 \mathrm{KK}$ України.

Ключові слова: незаконний видобуток бурштину, криміналізація, кримінально-правова норма, Кримінальний кодекс, диспозиція, формалізація

\section{Некоторые проблемные вопросы криминализации незаконной добычи янтаря}

$$
\text { Ю.А. Турлова }{ }^{1}, \text { Г. С. Полишук }{ }^{2}
$$

1 - Национальная академия прокуратуры Украины, г. Киев, Украина, e-mail: turlova@ukr.net

2 - Национальная академия внутренних дел, г. Киев, Украина

Цель. Исследование криминализации посягательств, связанных с незаконной добычей янтаря, имеющее самостоятельное значение как для законотворческой, так и правоприменительной деятельности.

Методика. Система общенаучных и специальных методов и подходов, которые обеспечили объективный анализ исследуемого предмета, в частности, формальнологический, логико-нормативный, документальный методы, а также метод статистического анализа.

Результаты. Выявлены некоторые проблемы, имеющие место при законодательном формировании уголовно-правового запрета исследуемых уголовных практик, в том числе - несоответствие криминализации незаконной добычи янтаря предпосылке относительной распространенности, а также имеющуюся пробильность закона об уголовной ответственности за контрабанду янтаря и групповой составляющей незаконной добычи янтаря и связанных с этим действий.

Научная новизна. В статье впервые проанализирована новелла уголовного законодательства - статья $240^{1}$ «Незаконная добыча, сбыт, приобретение, передача, пересылка, перевозка, переработка янтаря» УК Украины и соответствующие законопроекты на предмет соответствия требованиям теории криминализации, что позволило обосновать предложения, направленные на совершенствование действующего уголовного законодательства и практики его применения правоохранительными органами Украины в сфере противодействия незаконной добычи янтаря.

Практическая значимость. В работе исследовано соответствие норм, устанавливающих ответственность за незаконную добычу, сбыт, приобретение, передачу, пересылку, перевозку, переработку янтаря, такой предпосылке криминализации, как относительная распространенность. Сделан вывод, что незаконная добыча янтаря в понимании действующей редакции закона не соответствует указанной предпосылке. Аргументирована авторская позиция о целесообразности построения нормы, устанавливающей основной состав преступления, как материальной, что обеспечило бы более четкие критерии криминализации. Предложена формализация последствий незаконной добычи янтаря, объект которой наполнен экономическим содержанием, путем количественного оценивания причиненного преступлением вреда. Это позволит отобразить причиненный ущерб с помощью экономических категорий и обеспечит большую действенность в правоприменительной деятельности. Доказана целесообразность дополнения диспозиции части 2 статьи $240^{1}$ УК Украины таким квалифицирующим признаком как совершение указанного преступления по предварительному сговору группой лиц, а также криминализации контрабанды янтаря путем внесения соответствующих дополнений в часть 1 статьи 201 УК Украины.

Ключевые слова: добыча янтаря, криминализация, уголовно-правовая норма, Уголовный кодекс, диспозиция, формализация

Recommended for publication by O. O. Knyzhenko, Doctor of Juridical Sciences. The manuscript was submitted 16.03.20. 